\title{
GPSを利用した精密周波数源の周波数变動に対する検討
}

\author{
非会員 塩 田智 基 (日本大学) \\ 正 員 万 寿 邦 彦 (日本大学) \\ 非会員 黨 塚 日出夫 (キンセキ株式会社) \\ 正 員 関 根 好 文 (日本大学)
}

\section{A study on Frequency Stability of High Precision Oscillator using GPS}

Tomoki Shioda, Non-member (Nihon University), Kunihiko Manju, Member (Nihon University), Hideo Otsuka, Non-member(Kinseki Ltd.),Yoshifumi Sekine, Member (Nihon University)

\begin{abstract}
This paper studies on high precision oscillator using GPS. In recent years, the high stabilization of the oscillator has been requested along with high speed of mobile communication devices.

In this paper, first, we study on the relation between the number of measurement times and precision of the GPS reception signal. Because SA(Selective Availability) was canceled from May 2000, the precision of the received GPS signals is improving at present. Therefore, there is a possibility that we can decrease the integration number of measurement times. We show that integration with approximately $10^{3}$ times must be done. As a result we show that equal or superior stability is obtained at $1 / 10$ the previous integration number of time.

Also, the GPS reception signal has the high stability for the aging characteristic. We study on improvement of aging characteristic of crystal oscillator by using estimate function. As a result, we show that the frequency change reducing method by the aging characteristic revision is effective.
\end{abstract}

キーワード: 精密周波数発生源, 水晶発振器, エージング, GPS

keywords : High Precision Frequency Source, Crystal Oscillator, Aging, GPS

\section{1 まえがき}

近年移動体通信機器の高速化に伴い, 周波数発振源の高安 定化が求められている。精密周波数源である原子発振器は, 温 度や電源なよ゙の变動に上る周波数变動を軽減させるため, 比較 的,システムが複雑になる傾问があり，一般に，高価である。そ のため, 精密周波数をより手軽に得る力法が求められている。 最近ではGPS(Global Positioning System)の信号老利用するこ とで, 原子発振器レバルの出力精度を得る力法が期待されてい

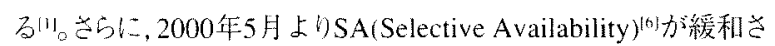
れ、GPS受信信号の精度が向上したため,ささらなるシステム改善 が期待できる。我々は先にGPS在利用した発振源として制御 ルーブを構筑し,精密発振源について報告したは3。本システムで はGPSから受信される1[pps]時㣏同期信号の短期安定度をGPS 本来の原子発振器レベルの精度に近づけため積分を行って いる。1 pps]時刻同期信号はSAが緩和した現在でも劣化してい る。

今回, SAの緩和により,積分回数を減少可能上考え, SA䋸和 㣪のGPS受信信号索測定し,皘分回数との関倸を示す。

次に, システム内の水晶発振器のエージング特性を, 過去の データをもとにした子予測関数在用いて周波数の変動考予測し， 補正在行う力法について示す。さらに, 実際の測定デー夕を用 い, その予测関数の有效性について確認する。

\section{GPSを利用した精密周波数源}

GPSは, 㾝続的に測位可能な衛星航法システムで,位置情報 の他に世界協定時(UTC)に同期した1[pps]時刻同期信号を得る ことができる。この1[pps]時刻问期信号は, 基準発振源としては GPSの衛星内のセシウム, 又はルビジウム原子発振器が用いら 机ており，長期安定度が優机ている。本来は短期安定度も優れ ているか，SAにより意図的にノイズを付加されているため,短 期安定度は十分でない。そこで, 短期安定度の優机た水晶発振 器と組み合わせることにより精密周波数発生システムを構成し ている。GPSを利用した精密周波数発生システムの回路構成に ついては载つか報告がなされているい|l12!

図1に,我々が考案した精密椆波数発生システムの構成図を 示す。まず,GPS Receiverから出力される1[pps]時刻同期信号を 基準信号としてCounterのGateに人力し,VC-OCXO(Voltage Controlled - Oven Controlled Crystal Oscillator ${ }^{|4|}$ の周波数を䁚 定しComputer出力寸る。次に, Computerが補正值を算出し, そのデシタル出力をD/Aコンバー夕(DAC)を介してVC-OCXO 制御電压VcとしてVC-OCXOに㷌還することで周波数变動索 補正する構成となっている。 


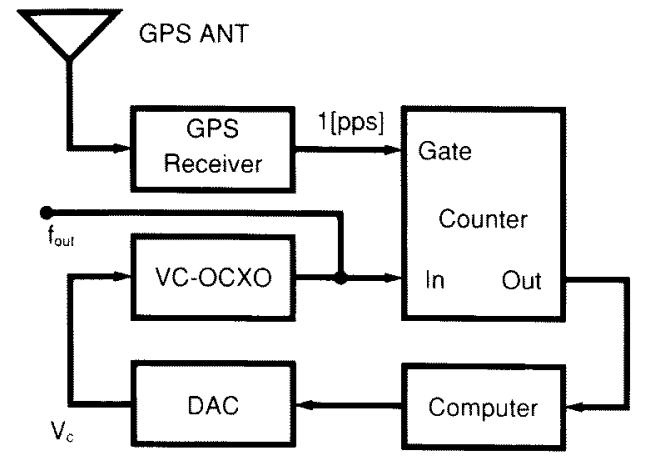

図1 GPSを用いた精密周波数源

Fig.1 High Precision Frequency Oscillator using GPS

図2に,GPS Receiverから取得できる1[pps]時刻同期信号の周 波数特性の模式図を示す。同図は1[pps]時刻同期信号は長期 では安定していることを示しているが, 短期でみるとSAにより 意图的にノイズが付加されたため变動していることを示してい る。GPSは内部基準として原子発振器を使用しているので,この 短期的変動分を除去するこよにより原子発振器レベルの精度 を得ることが可能と考え, 本システムでは，この短期的变動分を 除去する方法上して積分を用いた。

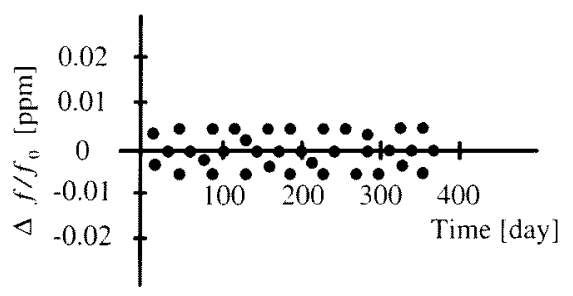

[图2 1[pps]時刻同期信号の周波数特性模式図 Fig.2 Frequency Characteristic Image of 1 [pps] Time Synchronous Signal

次に, 図3に水晶発振器の周波数特性の模式図を示古。同図 は,短期で見ると安定しているが, 長期で見ると水晶振動于の エージング特性などにより周波数が变動することを示している。 図1のシステムではこの長期的変動分を長期で安定してい る1[pps]時刻同期信号により補正し，補正値をComputerに蓄積 している。その蓄積したデータを用いてエージング特性の予測 関数を作成し,水晶振動子のエージンダなどによる長期的変動 分を補正している。

このような構成により,水晶発振器の短期安定度の良さと， GPSの長期安定度の良さを合わせ持つ精密周波数の発生が期 待できる。

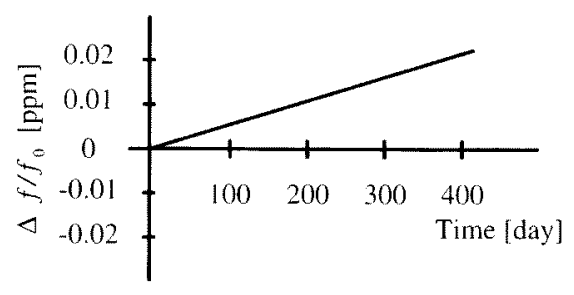

図3 水晶振動子の周波数特性模式図

Fig.3 Frequency Characteristic Image of Crystal

\section{3. 樍分によるGPS時刻同期信号の 周波数変動軽減}

GPSの1[pps]時刻同期信号は,SAによりノイズが付加されて いた。2000年5月2日13:00よりSAが緩和したため，現在では， 2000年5月以前に比心゙精度が问上している。しかし，現在でも1 [pps]時刻同期信号は变動している。1 [pps]時刻同期信号は,世 界協定時に対して同期が取られているため，1[pps]時刻同期信 号の周波数变動による影響は,その周波数变動分を積分するこ とにより，精度をさらに向上させることができる。

図にに执いて,CounterはVC-OCXOの周波数 $\mathrm{f}_{\mathrm{ou}}$ を, 1[pps]時 刻同期信号の精度で測走するため,Counterの出力結果はf 近で変動した值となる。そこで, 1秒毎に出力狄るCounterの出 力結果を,Computerで一定時間積分することで, $1[\mathrm{pps}]$ 時刻同 期信号の周波数变動分を軽隇できる。この方法によって, 高い 精度で $f_{\text {out }}$ を測定することができる。

$1[\mathrm{pps}$ 時刻同期信号は，SAが緩和した現在でも予測不可能 で不規則な变動をしている。その不規則な周波数变動成分を木 ワイトノイズとみなし, 検討を行った。

図4に,シミュレーションに用いた乱数系列を示す。同図は,周 波数変動範围を土1のホワイトイイ゙である。

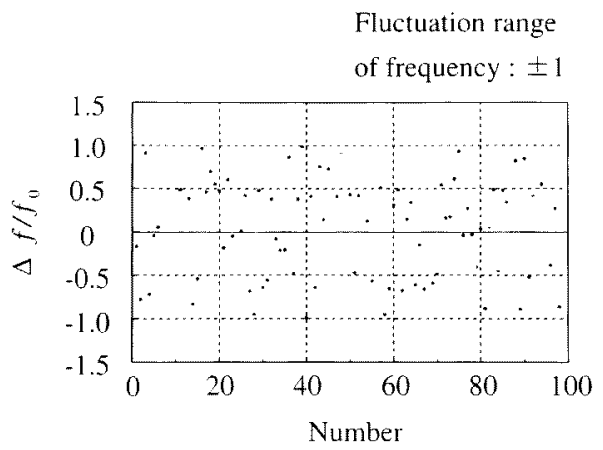

图4 乱数系列

Fig.4 Random Series 
図5に、図4のデー夕を、104可までの稓分を行った䑚波数変化 率特性老示す。同図は,棈分问数の增加に伴い周波数变化の範 囲が10-以下に減少していることを示しているここ机より,積分 が周波数变動の軽減に有効であること老確認した。

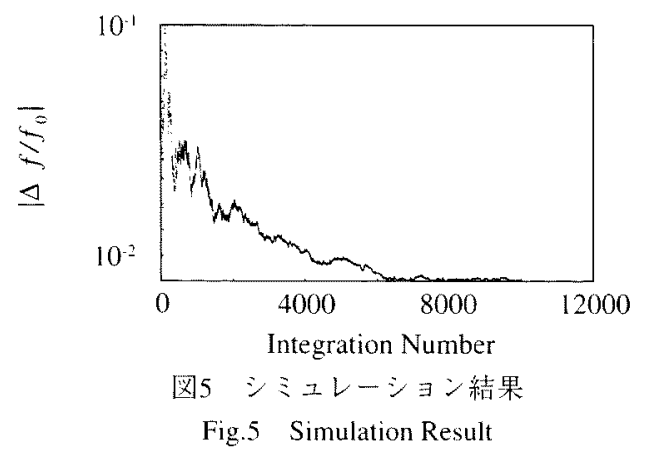

次に, 実測デー夕を用いて周波数变動軽減効果について検 討を行った。

図6に,SA緩和後の1[pps]時刻同期信号を測定した周波数変 化率老示す。同図は, 1 [pps]時刻同期信号の精度が $\pm 0.01[\mathrm{ppm}]$ であることを示している。GPS受信機にはGT-74NNNCを使用 L, Time Interval Analyzer(HP5371A)の基準にはルビジウム原 子発振器を使用した。

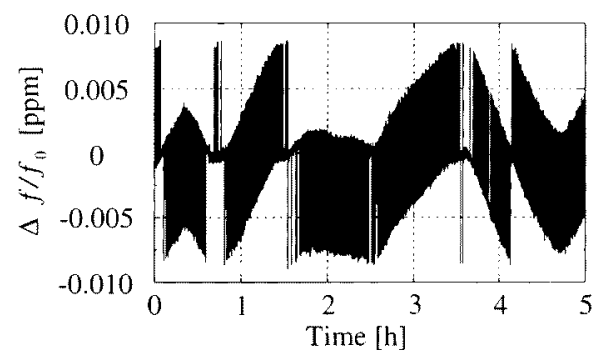

図61[pps]時刻同期信号

Fig.6 1[pps] Time Synchronous Signal

困7に，図6のデータを積分した結果を示す。図8に，積分回数 950回から1150回までの搪大図走す。同図は,システムの周 波数安定度を,仮にセシウムもしくはルビジウム原子発振器並 みの10"1のの精度と設定した場合，10"1の精度を実現するために は抢よそ10 回以上の積分回数が必要であることを示している。 これは図1のシステムにおいてて Counterの出力結果をComputer によって $10^{3}[\mathrm{~s}]$ 以上積分を行うことによってf 度で出力できることを示している。

2000 年 5 月以前に同様の検討を行った結果, 目標精度 $10^{\text {11 }}$ 実現するためには，抢よそ104回の積分を行う必要があることを 示しだ31。それに対し今回は, およそ103回の積分回数で目標精 度10“1を実現できることを示したっつまり，1/10の積分回数で今 までと同等の安定度を得られることを確認した。

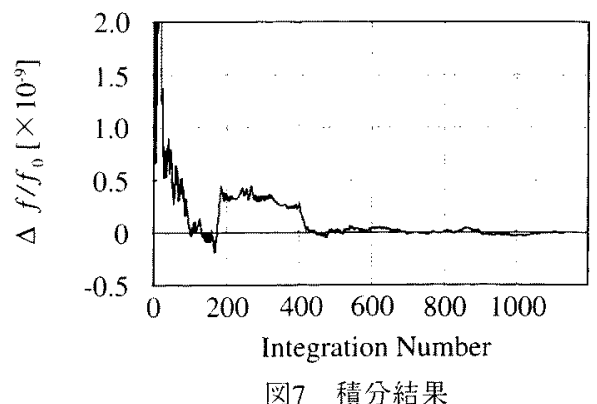

Fig.7 Integral Result

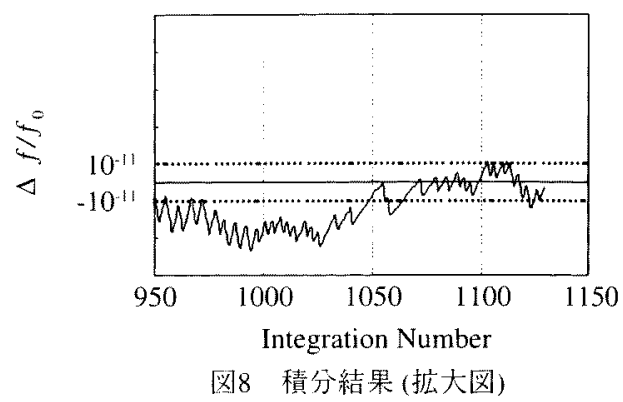

Fig.8 Integral Result (Magnification)

\section{4. エージング特性補正による周波数変動軽減}

\section{4-1. 原理}

次に, 水晶発振器のエージング特性による周波数变動を予測 し，予測関数を作成することによってリアルタイムに補正を行う 方法について検討した。

図9に水晶振動子の一般的なエージング特性として考えられ ている3種類の特性(1),(2)，(3)の概略図を示す。同図の特性は Exponential関数で表すことができ，一般式はは次式のように示 される。

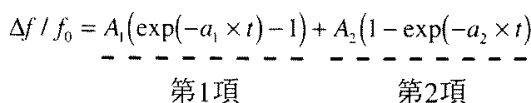

第 1 項

第2項

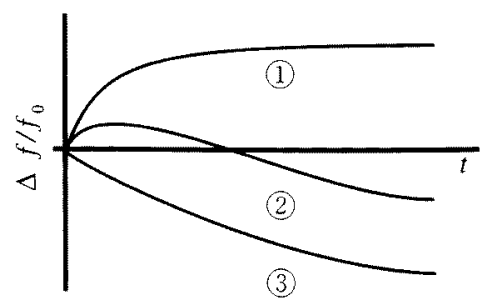

図9 一般的な水晶のエージング特性

Fig.9 Aging Characteristic of General Crystal 
式(1)に掠いて、第1項は動作以㖟に污染が発生する過程を示 しており，時間とともに周波数が隇少する項で，この項が支配的 な場合, 図9に扔ける(3)特性となる。第2項は動作以前の企, 污 染などが解消する過程を示し，時間とともに周波数が增狱する 項で,この項が支配的な場合，图9に㧍ける(1)の特性となる。 た第項と第2項の合成の例が(2)の特性に相当する。こ机らの 特性をもとに,式(1)を予測関数とした。

图1のシステムでは、第3章でも述べたように1[pps]時刻同期 信号によってVC-OCXOの周波数変動を補正している。その補 正值をComputerに蓄積しており，この補正データから振動子の エージンダ特性に近いデータが取得できる。取得したエージン グデー夕を利用することによって,Computerにより予測関数を 作成し，補正信号の出力をすることによってシステムへ適用す る。

本手法では, 数式的な解析が困難であるので,エージング データへ最小二乗法を適用し予測関数を決定している。今回の 㛟討ではエージンダデータに予測関数のフイッテイングを繰り 返す方法をとったフィッティングは残差二乗和 で行い,予測関数の各倸数 $A_{1}, a_{1}, A_{2}, a_{2}$ 老決定した。

t時刻から $t_{n}$ 時刻までのエージングデータを $f_{1} ー f_{n}$ としたときの 残差二乗和 $\psi$ は, 式(1)在用いると次式で示せる。

$$
\psi=\sum_{i=1}^{n}\left\{f_{i}-\left\{A_{-}\left(\exp \left(-a_{1} \times t_{i}\right)-1\right)+A_{2}\left(1-\exp \left(-a_{2} \times t_{i}\right)\right)\right\}\right\}^{2}
$$

たたし $, a_{1}>0, A_{1}>0, a_{2}>0, A_{2}>0$ とした。

ここで, $\psi$ が最小点をとる $f_{i}$ の条件を,式(2)の第1項，第2項それ ぞれについて検討した。

\section{4-2. 第1項に対する検討}

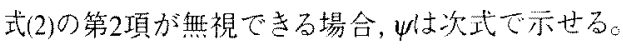

$$
\psi=\sum_{i=1}^{n}\left(f_{i}-A_{i}\left(\exp \left(-a_{1} \times t_{i}\right)-1\right)\right)^{2}
$$

ここで,

$$
y_{\mathrm{th}}=f_{i}-A_{1}\left(\exp \left(-a_{1} \times t_{i}\right)-1\right)
$$

とおくと,式(3)は次式で示せる。

$$
\psi=\sum_{i=1}^{n}\left(y_{11}\right)^{2}
$$

図10は, $A_{1}>\left|f_{i}\right|$ のきの $y_{1 i}$ の軌跡を示している。図中, 実線は $f_{i} \geqq 0$ の場合, 破線はf $f_{i}<0$ の場合である。

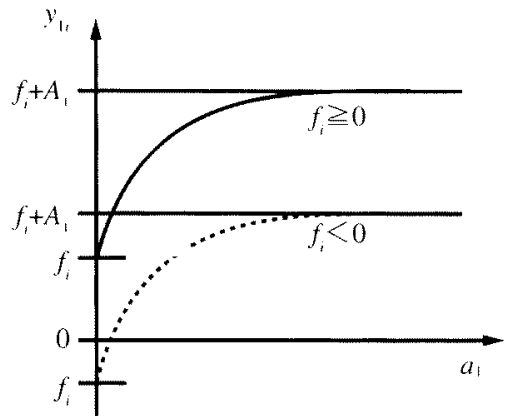

図10 $y_{1 i}$ の軌跡

Fig.10 Locus of $y_{1 i}$

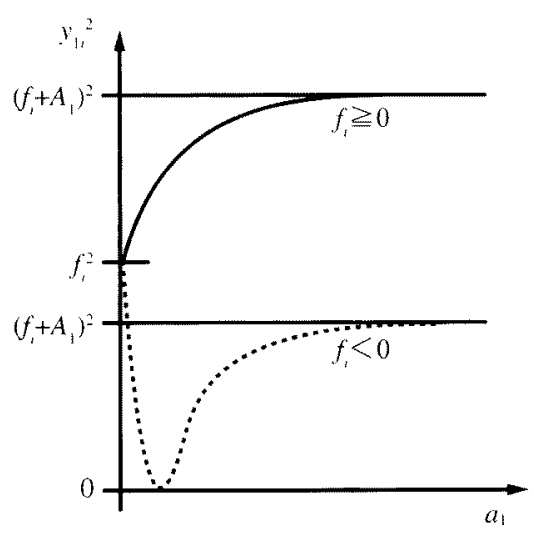

図11 $y_{11}^{2}$ の軌跡

Fig.11 Locus of $y_{1 i}{ }^{2}$

図11に, $f_{i} \geqq 0$ (実線), $f_{i}<0$ (破線)の条件に打ける, $y_{1}{ }^{2}$ の軌跡を 示す。同図は, $y_{1}{ }^{2}$ は $A_{1}>\left|f_{1}\right|, f_{1}<00$ 条件で, 最小点老有すること を示している。

つまり，第1項は式(5)で表されることより，A $>\left|f_{i}\right|, f_{i}<0$ 条件 の場合，40最小値が決定できる。

\section{4-3. 第2項に対する検討}

次に第2項についても第1項と同様に考元る。 式(2)の第1項が無視できる場合，次式で示せる。

$$
\psi=\sum_{i=1}^{n}\left(f_{i}-A_{2}\left(1-\exp \left(-a_{2} \times t_{i}\right)\right)\right)^{2}
$$

$こ こ て ゙$

$$
y_{2 t}=f_{1}-A_{2}\left(1-\exp \left(-a_{2} \times t_{4}\right)\right)
$$

と扔くと,式(3)は次式で示せる。

$$
\psi=\sum_{i=1}^{n}\left(y_{2 t}\right)^{2}
$$

図12は， $A_{2}>1 f_{1} \mid \sigma と き の y_{2}$ の軌跡を示している。図中, 実線は $f_{i} \geqq 0$ の場合，破線は $f_{i}<00$ 場合である。 


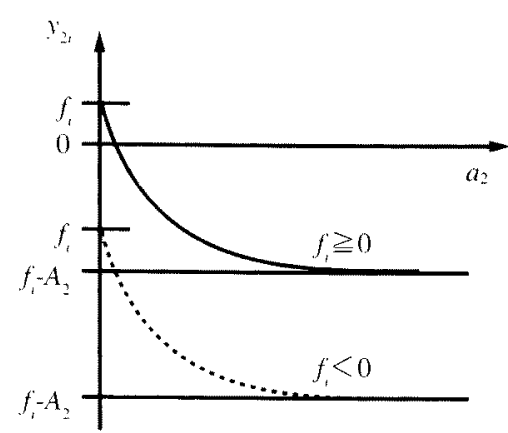

图 $12 y_{2 t}$ (軌跡

Fig.12 Locus of $y_{22}$

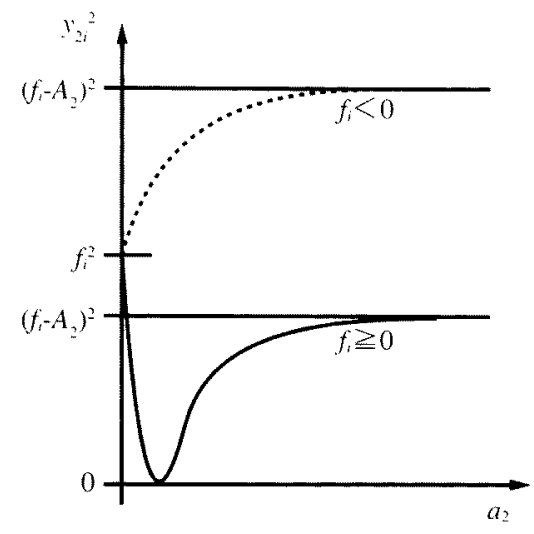

図13 $y_{2}^{2}=$ 軌跡

Fig. 13 Locus of $y_{2 i}^{2}$

図13に, $f_{1} \geqq 0$ (寒線), $f_{1}<0$ (破線)の条件における, $y_{2}{ }^{2}$ の軌跡を 示す。同闵は, $y_{2 t}{ }^{2}$ は $2 A_{2}>\left|f_{1}\right|, f_{1} \geq 0$ の条件で, 最小点を有すること 走している。

つまり，第2項は式(8)で表光机ることより，A $A_{2}>\left|f_{1}\right|, f_{i} \geq 0$ 条件 の場合，孜小値が決䇥でき局。

以上, 表に最小点の関倸走示す $A_{2}>\left|f_{1}\right|$ の条件で予測関数 が最小点孝有することを示し，収柬可能で南ることを明らかにし た。

$$
\text { 表1 最小点 }
$$

Table.1 Minimum Point

\begin{tabular}{|c|c|c|}
\hline$f i$ & $f_{i}<0$ & $f_{i} \geqq 0$ \\
\hline 最小点 & 笰1 項 & 第2項 \\
\hline
\end{tabular}

\section{4-4. 結果}

本手法の有効性について実測データを用いたシミュレーショ ンを行った。一般的なエージング特性は図9に示したように3種 粸のパ夕ーンを有していると考えられている。そこで, 今回それ ぞ机のハターンに対応する寒測デー夕について梌証在行った。

図14〜16に，娭証に使用したエージング特性の実測データ (四中before)走示 $|5|$ 。

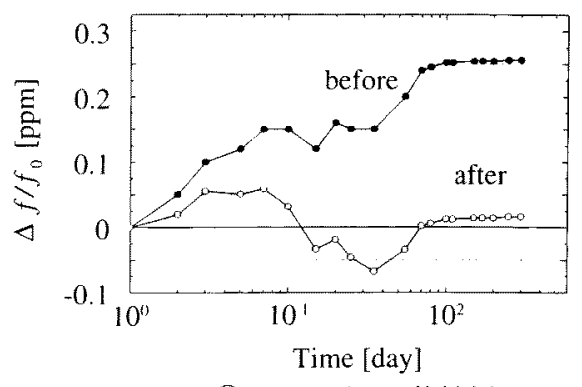

図14(1)のエージング特性例

Fig. 14 Example of Aging Characteristic about (1)

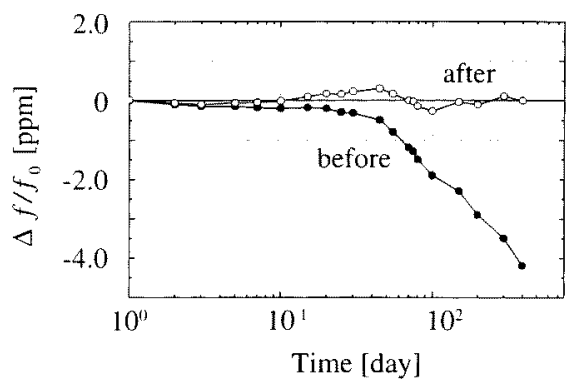

図15 (3)のエージング特性例

Fig.15 Example of Aging Characteristic about (3)

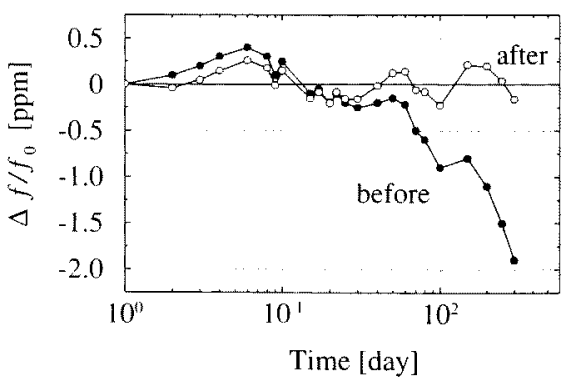

図16(2)のエージング特性例

Fig.16 Example of Aging Characteristic about (2)

四14１6に，エージング特性補正後の結果(図中after)走 す。図14は，補正前では周波数变化率が $0.25[\mathrm{ppm}]$ であるが，補 正徭は0.13[ppm]となり, 周波数変化が減少できることを示して いる。図15は, 補正前では周波数変化率が4.30[ppm]である゙， 補正徭は $1.00[\mathrm{ppm}]$ となり，周波数变化が減少できることを示し ている。図16は，補正前では周波数变化制が $2.30[\mathrm{ppm}]$ である が、補正後は0.50[ppm]となり，周波数变化が減少できることを 示している。

以上，一般的な3種類のエージング特性に対して，それぞれ周 波数变動を改善できることを示し，今回検討したエージング特 性補正による周波数変動軽減法の有効性を示した。 
さらに,本手法は, GPSの受信が一時的に途絶えた場合や,起 動直後なよ゙,GPSから受信時間が十分でない場合でも、水晶発 振器のエージング特性を予測することが可能なため, 常に精密 な周波数を得ることができ,有効な手法といえる。

\section{5.むすび}

今回, SAの緩和により,積分回数を变更できる可能性がある と考え,SA緩和㣪のGPS受信信号の精度を測定し, 積分回数に ついて検討を行ったその結果, 目標精度10-1をを実現するため には拉よそ10?回の積分回数が必要であることを示したっつまり 1/10の積分回数で今までと同等の安定度を得られることを確認 した。

さらに,システム内の水晶発振器のエージングを予測関数の 導出によって補正する方法について検討し, 実際のエージング データを用い, その予測関数の有効性について確認を行った。 その結果,一般的な3種類のエージング特性に対して, 周波数変 化を減少できることを示し、今回娭討したエージング特性補正 による周波数変動軽減法の有効性を示した。

今後は, エージング特性補正による周波数变動軽減法にお いて, 予測関数を周波数データにコイッティングを行う際, 収束 值の妥協点, 決定方法について検討し, 実際のシステムに組み 込む際に要求される補正間隔について検討していく予定であ 万:

(平成 13 年 7 月 16 日受付、同 14 年 1 月 4 日再受付)

\section{文献}

[1] 氏家仁:“GPS 利用した精密周波数発生器”, 電気学会計測研资, IM-97-42, pp.21-26, (1997)

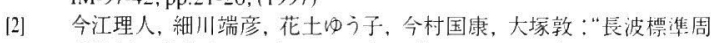
波数局の整備とその応用”, 電気学会電子回路研資, ECT-97-88, pp.13-17, (1997)

[3] 小松原円，関根好文: “GPS老利用した精密周波数源の温度特性に対 する一検討”, 1998年信学ソ大, A-1-8, (1998)

(4)岡野庄太郎: “水晶周波数制御デバイス”,テクノ,pp.97-139,(1995)

[5]岡野庄太郎, 高沢幸次: “特集・半導体時代の水晶発振器” 電子 展望, 誠文堂新光社

[6] 例えば “Interagency GPS Executive Board” URL http://www.igeb.gov/sa/

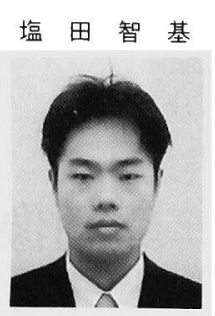

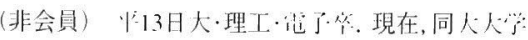
院博上前期橦程在学中, 水晶発振器, 精密周波数源 に阅する研究に従事。巣子情報通信学会会員。

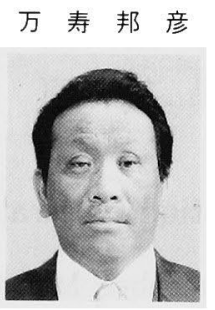

（此具）昭50日大·生産工.電気卒. 同年同大勤䅂, 現在, 日大尃任講師, 生産工·電気電子勤務, 主に卜 ランジスタ水晶発振器, CAI, 衛星を用いた応用計測 などの研究に従事. 電子情報通信学会, 日本シミュ レーション学会各会員.

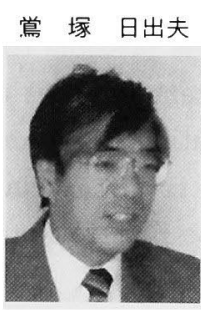

(非会員) 昭49日大·理工.電気卒. 昭51同大大学 院修士課程修了. 同年キンセキ(怢) 入社. 現在, 同 社産業機器七ンター所属. 水晶発振器及び水晶振 動子の研究開発に従事.

関 根 好 文

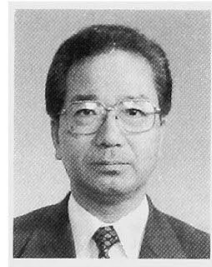

(正員) 昭41日大·理工·電気卒. 昭43同大大学院 修士課程修了同年日大助手. 現在, 同大電子情報 工学科教授. 工博. 主に負性抵抗素子, 発振回路, ハードウェアニューロンモデル, 及び, その応用に関 する研究に従事. 著皆電子計測」「エレクトロニク 不計測」,「ディジタル回路」.IEEE, 電気学会, 日本 神経回路学会, 時計学会各会員. 